\title{
HUMAN RELATION DALAM PERSPEKTIF ISLAM
}

\author{
Andi Zuchairiny \\ STAIN Datokarama Palu, Jl. Diponegoro 23 Palu \\ e-mail: zuchairini@yahoo.co.id
}

\begin{abstract}
Human relation in a contemporary management, which places human beings in a proportional position, is so important that it should be paid serious attention. In Islamic perspective, human relation also emphasizes human beings as the most honored creatures who have various rights and obligations which must be complied with and respected. Its ultimate goal is to create the spirit of Islamic fraternity. However, this Islamic concept of human relation has not been translated yet into practice until these days.

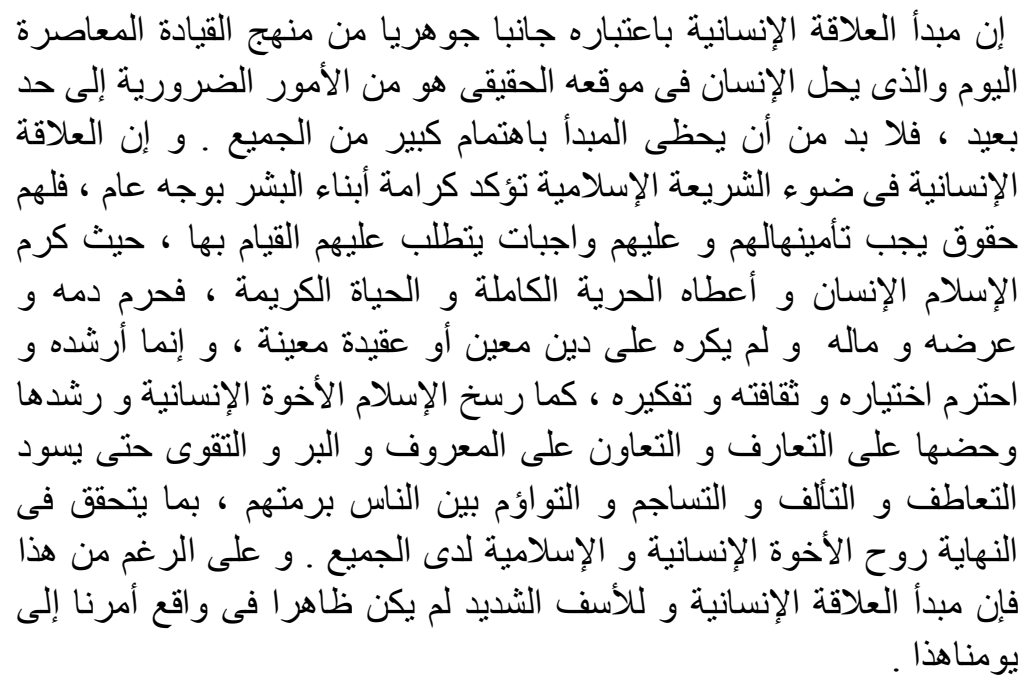

Kata Kunci: human relation, manajemen organisasi, interaksi sosial, ukhuwat islâmiyah 


\section{PENDAHULUAN}

Suatu hal yang sulit dipungkiri, yaitu kenyataan bahwa tidak sedikit manajer (pimpinan) yang gagal dalam menjalankan tugas dan fungsinya. Hal ini sebagian disebabkan oleh kurangnya perhatian pada aspek human relation dalam membangun semangat kebersamaan sebagai salah satu faktor yang sangat dominan dalam menunjang keberhasilan manajemen. Kajian ini bermaksud menelaah secara konseptual makna human relation dan urgensinya dengan menggunakan pendekatan psikologis dan sosiologis dalam prespektif Islam.

Secara faktual, dewasa ini terdapat suatu kecenderungan manusia dalam berhubungan dengan sesamanya, khususnya perlakuan manajemen dalam organisasi, lebih mengedepankan kepentingan material (produktivitas) sehingga masalah-masalah kemanusiaan, tata nilai, dan kebutuhan rohaniah sering terabaikan.

Dalam menghadapi problem konkret dalam kehidupan material dan perkembangan ilmiah, Barat telah kehilangan rasa supernatural (alam ghaib) secara besar-besaran. Bahkan Barat merasa heran bahwa yang gaib dan suci itu dapat memberikan premis (mukadimah) pada pendekatan pemikiran dan dasar-dasar organisasi kemasyarakatan (Boisard, 1980:79).

Human relation dalam prespektif Islam bukan sekedar pendekatan pemikiran dalam konsep tata hubungan kemanusiaan, melainkan tata nilai yang menjadi inti dalam proses interaksi sosial yang manusiawi, yang dimaksudkan untuk memenuhi hak dan kewajiban terhadap sesama manusia.

Human relation dalam organisasi merupakan sebuah sistem yang melibatkan beberapa orang yang bekerjasama untuk mencapai tujuan bersama. Untuk mencapai tujuan tersebut secara maksimal harus ada dukungan tata kerja dan interaksi secara harmonis dan manusiawi sebagai suatu kesatuan dari elemen-elemen yang ada.

Berdasarkan pemikiran di atas, muncul pertanyaan, yaitu (1) bagaimana hubungan human relation dengan manajemen? (2) bagaimana konsep human relation menurut Islam? 


\section{PENTINGNYA HUMAN RELATION}

Human relation terdiri atas dua kata, yaitu human dan relation. Secara kebahasaan, kata human berarti "manusia", sedangkan kata humane berarti "bersifat manusia", kata humanist berarti "peramah, orang yang penyayang, perikemanusiaan" (Echols \& Shadily, 1990: 306). Dalam Kamus Internasional Populer, humanest berarti "ajaran atau paham kemanusiaan, menganggap manusia-manusia lain mempunyai nilai, kepentingan-kepentingan dan hak-hak serta kewajiban-kewajiban yang sama sebagai layaknya manusia" (Redaksi Karya Anda, t.th.:164). Sedangkan kata relation berarti "hubungan" (Echols \& Shadily, 1990:475). Dari pengertian tersebut, dapat dipahami bahwa human relation adalah hubungan atau interaksi yang terjadi antara seseorang dengan orang lain atau dengan sekelompok orang, baik dalam organisasi maupun dalam masyarakat yang berlangsung secara manusiawi.

Makna hakiki dari human relation bukanlah human dalam pengertian wujud manusia (human being), melainkan makna dalam proses rohaniah yang tertuju kepada kebahagiaan berdasarkan watak, sifat, perangai, kepribadian, sikap, tingkah laku dan lain-lain, yang merupakan aspek kejiwaan yang terdapat pada diri manusia. Oleh karena itu, maksud human relation adalah hubungan manusiawi atau hubungan insani (Effendy, 1993:41).

Peristiwa yang terjadi, misalnya seorang karyawan suatu perusahaan atau instansi berkata kepada teman sekerjanya bahwa direktur atau pimpinan kita itu ada hubungan keluarga dengan saya. Lalu teman tersebut tersenyum. Antara si karyawan dengan direktur terdapat hubungan, baik hubungan kekeluargaaan maupun hubungan kerja, tetapi hubungan tersebut adalah hubungan manusia atau hubungan antarmanusia, bukan human relation. Atau, peristiwa seperti perkataan seorang suami kepada istrinya, "Bu, saya nanti pulang dari kantor agak terlambat karena banyak tugas tambahan yang saya harus selesaikan". Jawab sang istri, "Pak, pulangnya jangan terlalu malam, nanti terjadi apa-apa di jalan". Dialog singkat ini bukan merupakan human relation, meskipun terjadi hubungan atau komunikasi dua arah.

Dalam peristiwa lain, seorang guru pulang dari menerima gaji, yang disambut sang istri dengan rasa gembira, lalu berkata kepada suaminya, "Pak sejak kita menikah sampai mempunyai anak dua sekarang, kalungku hanya ini saja dari emas imitasi, aku ingin sekali 
kalung emas yang baru." Sang suami terdiam, lalu berkata kepada istrinya, "Bukan papa tidak sayang padamu Bu! Tetapi aku pikir ada yang lebih penting dari itu, bagaimana pendapatmu kalau gaji bulan ini kita belikan lemari pakaian agar pakaian yang berserakan dapat tersimpan rapi. Aku berjanji gaji bulan depan insyaallah akan kubelikan kalung emas untukmu. Bagaimana Bu?" "Betul juga pendapat Bapak, aku sangat setuju," jawab istri dengan wajah cerah.

Dialog antara suami dan istri tersebut merupakan suatu contoh proses human relation karena terjadi kegiatan komunikasi, dan yang dituju kedua belah pihak merasa puas. Human relation bersifat actionoriented, bukan hubungan yang pasif dan yang dituju adalah kepuasan batin. Oleh karena itu, human relation banyak diterapkan dalam manajemen (Effendy, 1993:42).

Dari beberapa peristiwa dan pengertian yang disebutkan di atas, terkandung suatu pengertian bahwa human relation dapat dipahami sebagai interaksi yang dilakukan seseorang kepada orang lain dalam segala situasi dan dalam semua bidang kehidupan, yang dapat menimbulkan kebahagiaan dan kepuasan hati kedua belah pihak.

\section{MANUSIA DALAM HUMAN RELATION}

Dalam teori manajemen, human relation merupakan titik sentral yang paling dominan dalam menentukan berhasil atau tidaknya aktivitas organisasi dalam mencapai tujuannya. Namun demikian, perlu dipahami pula bahwa inti dari human relation adalah manusia. Dalam hal ini, perlu dikaji lebih dahulu siapa sebenarnya manusia itu? Fattah (2000:17) memaparkan beberapa pandangan yang berbeda tentang manusia:

- Pandangan psikoanalitik tradisional menganggap bahwa manusia pada dasarnya digerakkan oleh dorongan dari dalam dirinya yang bersifat instingtif. Tingkah laku individu ditentukan dan dikontrol oleh kekuatan psikologis yang sejak semula sudah ada pada diri individu itu.

- Pandangan humanis mengemukakan bahwa pribadi individu merupakan proses yang terus berjalan, suatu kekuatan yang tidak statis. Individu merupakan satu kesatuan potensi yang terus berubah. Manusia pada hakikatnya tidak pernah selesai, tidak pernah sempurna. 
- Pandangan humanis berpendapat bahwa manusia tidak semata-mata digerakkan oleh dorongan untuk memuaskan dirinya sendiri, namun sebaliknya manusia digerakkan dalam kehidupannya sebagian oleh tanggung jawab sosial dan sebagian yang lain oleh kebutuhan untuk mencapai sesuatu.

Perilaku manusia yang cenderung berbeda ini dipengaruhi oleh beberapa faktor, antara lain faktor individu, faktor lingkungan dan faktor organisasi, yang berimplikasi terhadap pelaksanaan manajemen. Pada prinsipnya orang bekerja untuk memenuhi kebutuhannya, sebagai penggerak atau pembangkit perilaku, terutama kebutuhan jiwa, berupa kesenangan, keamanan, kebersamaan, dan kepuasan batin. Ketika kebutuhan tersebut tidak terpenuhi secara proposional, dengan sendirinya akan mengurangi motivasi kerja seseorang.

Manusia dalam kaitannya dengan human relation merupakan inti dari segala aktivitas yang dilakukan. Dalam organisai atau perusahaan, Human relation adalah karyawan atau staf yang membutuhkan perhatian dan perlakuan yang manusiawi sesuai dengan harkat dan martabatnya.

Dalam penerapan human relation, seorang pimpinan perlu memahami sifat dan tabiat bawahannya, mengapa karyawan yang satu berbeda dengan karyawan lain, bagaimana tingkah laku orang yang dipimpinnya dalam kehihidupan berkelompok dan bermasyarakat (Effendy, 1993:53). Kegagalan sseeorang dalam human relation adalah akibat ketidakmampuannya memahami dan memperlakukan orang lain sesuai dengan karakter dan kebutuhannya, terutama kebutuhan rohaninya.

\section{HUMAN RELATION DALAM MANAJEMEN}

Human relation merupakan inti dalam manajemen karena pada hakikatnya proses pencapainan tujuan manajemen harus didukung oleh orang lain. Oleh karena itu, seorang manajer harus mampu berinteraksi secara efektif dengan orang yang dipimpinannya. Keberhasilan seorang manajer dapat diukur dari kemampuan dan ketepatannya dalam mengadakan human relation secara proporsional. Banyaknya waktu yang diluangkan dalam berkomunikasi oleh seorang manajer terhadap orang yang dipimpinnya tidak mejamin keberhasilan suatu manajemen karena tidak semua proses komunikasi 
yang dilakukan dapat terakumulasi dalam lingkup makna human relation.

Dalam proses komunikasi dikenal beberapa tahap, yaitu (1) tahap ideation, yaitu proses penciptaan gagasan; (2) tahap encoding, yaitu penyusunan informasi dalam berbagai bentuk dan pemilihan saluran; (3) tahap transmitting, yaitu tahap penyampaian pesan (4) tahap receiving, yaitu tahap penerimaan pesan; (5) tahap decoding, yaitu tahap penginterpretasian pesan yang diterima; dan (6) tahap tindakan feedback, yaitu tahap merespons pesan-pesan yang diterima (Jiwanto, 1985:13-14).

Proses komunikasi melalui enam tahap tersebut lebih menekannkan pada aspek hubungan manusia dengan sesama manusia, meskipun dalam hubungan tersebut tidak saling menyenangkan dan tidak menciptakan kepuasan batin dari kedua belah pihak.

Proses human relation dalam manajemen menekankan pada aspek rohaniah yang memungkinkan terciptanya kepuasan batin kedua belah pihak. Pemenuhan hak-hak terhadap sesama manusia merupakan faktor utama yang menjadi tolak ukur human relation dalam pelaksanaan fungsi manajemen.

Sejarah telah mencatat bahwa seiring dengan bertambahnya berbagai bentuk organisasi, semakin banyak pula ilmuan yang menaruh perhatian pada pertumbuhan teori manajemen, yang menimbulkan kesadaran bahwa manusia dalam organisasi apapun tidak dapat dan tidak boleh diperlakukan sebagai mesin (Siagian, 2001:39). Penelitian Elton Mayd dalam gerakan human relationi membuktikan bahwa bahwa ada faktor-faktor tertentu yang berpengaruh sikap sikap, perilaku dan produktivitas para pekerja. Temuan mereka menunjukkan bahwa sikap dan perilaku positif serta produktivitas para karyawan tidak terlalu dipengaruhi oleh fasilitas dan kondisi kerja, melainkan oleh perhatian manajemen pada mereka. Temuan kedua ialah bahwa perilaku seorang pekerja sangat ditentukan dan terikat oleh norma-norma kelompok kerja dimana seseorang menjadi anggota (Mayd dalam Siagian, 2001:39).

Hasil penelitan tersebut menunjukkan bahwa perkembangan teori manajemen kontemporer dalam kaitannya dengan pengembangan sumber daya manusia di Amerika Serikat telah menaruh perhatian yang cukup besar mengenai pentingnya human relation dalam manajemen organisasi atau perusahaan. Dengan kata lain, manusia 
tidak boleh diperlakukan sebagai mesin karena mereka membutuhkan perhatian, istirahat dan kepuasan batin. Perilaku positif dan tingkat produktivitas karyawan tidak dipengaruhi oleh aktivitasnya, tetapi perhatian yang diberikan oleh manajer pada mereka, selain normanorma yang dianut oleh kelompok kerja.

Iklim komunikasi yang penuh persaudaraan akan mendorong para anggota organisasi berkomunikasi secara terbuka, rileks, ramahtamah dengan anggota lain. Sebaliknya, iklim yang negatif menjadikan anggota tidak berani berkomunikasi secara terbuka dan penuh rasa persaudaraan (Muhammad, 2000:85). Dalam suasana persaudaraan, segala persoalan organisasi dapat diselesaikan. Semangat kebersamaan, keakraban, dan keterbukaan memungkinkan terciptanya rasa tanggung jawab dan semangat kerja dikalangan para anggota organisasi.

\section{HUMAN RELATION MENURUT ISLAM}

\section{Konsep Dasar Human Relation}

Pada bagian yang lalu telah dikemukakan pengertian human relation secara umum. Pada uraian ini secara spesifik akan dikaji konsep dasar human relation dalam perspektif Islam. Dalam Alquran terdapat beberapa ayat yang dapat dijadikan landasan filosofi tentang makna human relation seperti yang tersirat dalam ayat berikut:

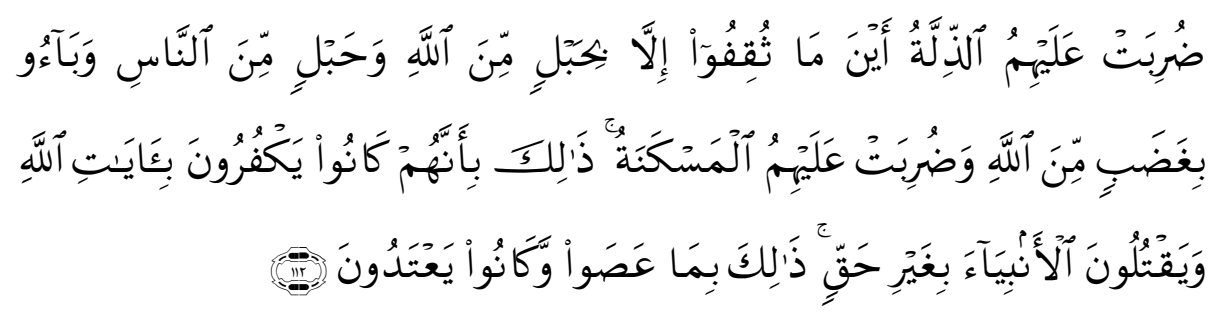

Terjemahnya:

Mereka diliputi suatu kehinaan dimana saja berada, kecuali bagi mereka yang berpegang (berpedoman) pada agama Allah dan tali perjanjian (hubungan) dengan sesama manusia (Q.S Âli 'Imrân [3]: 112)

Ayat tersebut mengandung makna yang sangat dalam, yaitu manusia-dalam situasi apapun dan dimana pun berada-selalu diliputi kehinaan, kecuali yang selalu memperbaiki hubungannya 
dengan Allah dan selalu memperbaiki hubungannya dengan sesama manusia. Secara kontekstual, ayat tersebut dapat dipahami bahwa meskipun manusia senantiasa beribadah kepada Allah, tetapi jika hubungannya dengan sesamanya tidak baik, mereka termasuk orang hina. Ini berarti bahwa hubungan yang harmonis dengan sesama manusia merupakan prasyarat dalam kehidupan mereka, dan bahkan merupakan bagian dari ibadah kepada Allah swt.

Dalam konteks ini, menurut Islam, human relation tidak sekedar hubungan kemanusiaan, melainkan juga suatu perintah yang wajib dilakukan. Hal ini sejalan dengan firman Allah swt.:

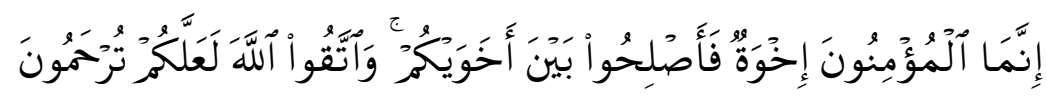

Terjemahnya:

Sesungguhnya orang mukmin bersaudara, karena itu damaikanlah di antara saudaramu (Q.S Al-Hujrât [49]:10).

Ada dua hal mendasar yang terkandung dalam ayat tersebut dalam kaitannya dengan human relation dalam manajemen yang islami, yaitu adanya konsep persaudaraan dalam kehidupan bersama; dan adanya perintah untuk selalu memperbaiki hubungan kemanusiaan dan selalu berusaha mendamaikan orang yang berselisih. Sehubungan dengan hal tersebut, seorang pimpinan yang bijaksana seyogyanya selalu merasa bersaudara dengan orang yang dipimpinannya dan selalu berusaha berdamai dan mendamaikan orang atau bawahannya yang bersengketa. Dengan cara ini, suasana damai, harmonis, bahagia, dan kebersamaan dapat diciptakan sehingga tujuan bersama dapat dengan muda pula diwujudkan.

\section{Proses Human Relation}

Proses human relation dalam konsep Islam mengacu pada "amar makruf nahi mungkar" dalam upaya memenuhi hak-hak dan kewajiban terhadap sesama manusia. Perintah melaksanakan hak dan kewajiban terhadap sesama manusia adalah berdasarkan pada salah satu hadis Rasulullah saw. yang diriwayatkan oleh Imam Muslim, sebagai berikut :

Dari Abû Hurayrah, sesungguhnya Rasulullah saw. bersabda: "Hak seorang muslim terhadap sesamanya ada enam, maka sahabat bertanya apa saja yang dimaksudkan ya Rasulullah, 
lalu nabi bersabda, "Apabila berjumpa hendaklah memberi salam, apabila kamu diundang maka perkenankanlah, apabila kamu membutuhkan nasihat (bimbingan) maka nasehatilah, apabila bersin lalu, memuji Allah maka hendaklah dibalas, apabila sakit hendaklah dikunjungi, dan apabila mati antarlah ke kuburnya" (Muslim, t.th:266)

Berdasarkan hadis tersebut, secara kontekstual dapat dipahami bahwa dari enam hak terhadap sesama muslim merupakan bentuk paradigma human relation yang islami dalam memenuhi hak-hak sesama muslim. Selain upaya memenuhi hak-hak terhadap sesama manusia, Islam lebih jauh memberikan petunjuk praktis dalam membina hubungan terhadap sesama manusia, sesuai dengan firman Allah swt. berikut:

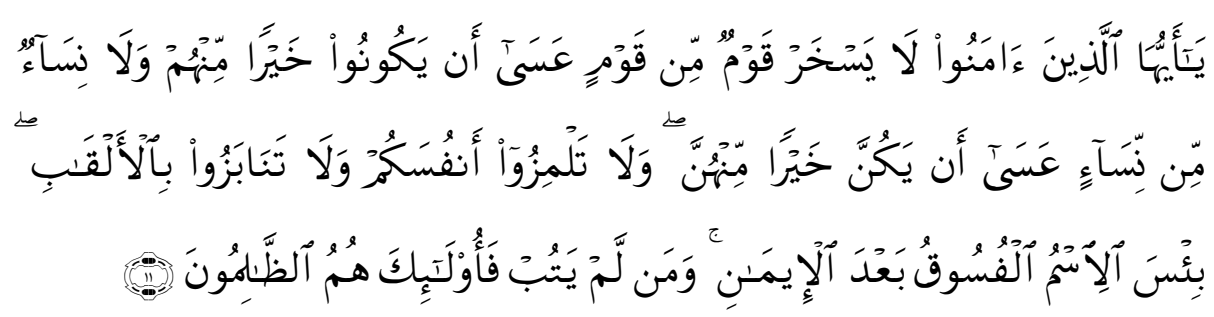

Terjemahnya:

Hai orang-orang yang beriman, janganlah suatu kaum mengolok-olok kaum yang lain (karena) boleh jadi mereka yang diperolok-olok lebih baik dari mereka mengolok-olok, dan jangan pula wanita-wanita mengolok-olok wanita-wanita lain, karena boleh jadi wanita-wanita yang diperolok-olok lebih baik dari yang mengolok-olok, dan janganlah kamu mencela diri sendiri dan janganlah kamu saling memanngil dengan gelargelar yang buruk. Panggilan yang terburuk ialah panggilan buruk sesudah beriman, dan barang siapa yang tidak mau bertaubat, maka mereka itulah orang-orang yang dzalim.Hai orang-orang yang berima, jauhilah banyak prasangka sesungguhnya sebahagian prasangka itu adalah dosa, dan janganlah kamu mencari-cari kesalahan orang lain, dan janganlah sebagian kamu mengunjing sebagian yang lain. Sukakah salah seorang di antara kamu memakan daging saudaranya yang sudah mati? Maka tentulah kamu merasa jijik kepadanya. Dan bertakwalah kepada Allah sesungguhnya Allah Maha Penerima Taubat lagi Maha Penyayang (Q.S Al-Hujurât [49]:11-12). 
Dalam dua ayat di atas terdapat beberapa petunjuk teknis yang dapat dijadikan pedoman dalam proses human relation, yaitu: (1) larangan saling mengolok-olokan; (2) larangan mencela diri sendiri; (3) larangan saling memanggil dengan gelaran yang buruk; (4) larang berprasangka buruk; (5) larangan mencari-cari kesalahan yang lain; (6) larangan menggunjing orang lain; (7) perintah untuk senantiasa bertakwa dan bertaubat; dan (8) Allah Maha Pengasih dan Maha Penyayang pada hamba-Nya.

\section{Prinsip Human Relation}

Prinsip-prinsip human relation dalam Islam merujuk pada landasan filosofis yang sesuai dengan esensi harkat dan martabat manusia sebagi makhluk yang mulia, sehingga harus diperlakukan secara arif, bijaksana dan manusiawi. Alquran memberikan petunjuk yang amat bijaksana dan manusiawi yang mengandung beberapa prinsip dasar yang perlu dikaji dan dikembangkan.

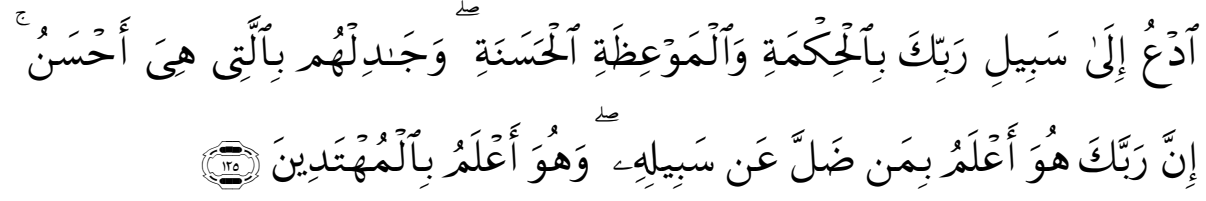

Terjemahnya:

Serulah manusia ke jalan Tuhanmu dengan arif dan bijaksana dan dengan bimbingan (pelajaran) yang baik, dan bantahlah (bermusyawarahlah) dengan mereka secara baik sesungguhnya Tuhanmu. Dia lah yang lebih mengetahui siapa yang bersesat dari jalannya dan Dialah yang lebih mengetahui orang-orang yang mendapatkan petunjuk (Q.S Al-Nah $\square 1$ [16]: 125).

Prinsip-prinsip yang terkandung dalam ayat tersebut adalah (1) perintah menyeru, mengajak dan membimbing manusia dengan berpedoman pada Alquran dengan cara yang bijaksana (berdasarkan teori ilmu); (2) memberikan bimbingan dan pelajaran yang baik dengan cara yang baik; (3) melakukan musyawarah (bantahlah) dengan cara yang baik; (4) hanya Tuhan yang mengetahui orang yang bersesat dan orang yang mendapatkan petunjuk. Dalam arti manusia mempunyai keterbatasan sehingga tidak akan tahu siapa yang salah (tersesat) dan siapa yang benar (mendapat petunjuk). 
Keempat prinsip tersebut terakumulasi dalam suatu pengertian bahwa agama adalah pelita kehidupan dan petunjuk pembentukan karakter kemanusiaan (Sya'ban, 1982:99). Sasaran pembentukan karakter manusia adalah jiwa manusia itu sendiri, apabila jiwa manusia itu baik, maka baik pula manusia itu. Hal ini sesuai dengan hadis Rasulullah saw.

Ketahuilah, bahwa sesungguhnya dalam diri manusia terdapat segumpal daging, apabila daging tersebut terpelihara dengan baik, maka baiklah manusia itu, dan apabila daging itu rusak, maka rusaklah manusi itu, ketahuilah bahwa yang dimaksudkan adalah hati (Umar, t.th: 42)

Hati adalah titik sentral yang menjadi penggerak dalam diri manusia. Oleh karena itu, segala upaya untuk membentuk perilaku, memberi motivasi, menciptakan ketenangan, kebahagiaan dan kepuasan dalam diri manusia, seyogyanya diarahkan pada perlakuan manusia secara manusiawi. Dalam hal ini, inti keberhasilan manajemen terletak pada human relation; inti keberhasilan human relation terletak pada manusia; dan inti keberhasilan manusia terletak pada kepuasan hati.

\section{PENUTUP}

Dari uraian di atas, dapat ditarik kesimpulan bahwa human relation adalah proses hubungan manusia dengan sesamanya yang berlangsung secara komunikatif dan manusiawi. Intinya adalah manusia, dan inti dari manusia adalah kepuasan rohaniah. Oleh karena itu, manusia membutuhkan perlakuan secara proposional dan manusiawi. Dalam perspektif Islam, human relation menempatkan manusia sebagai makhluk yang termulia, mempunyai hak dan kewajiban yang harus dilaksanakan dan dihargai dalam kehidupan bersama. Sasarannya adalah terciptanya semangat ukhuwat Islâmiyyah dalam tata pergaulan untuk mencapai tujuan bersama.

Dalam hubungan itu, konsep human relation - yang dalam sistem manajemen kontemporer menempatkan manusia (karyawan) pada proporsi yang sebenarnya - patut mendapatkan perhatian secara manusiawi walupun selama ini banyak dilecehkan dalam perlakuan manajemen yang ada. Aplikasi konsep human relation yang islami yang secara konseptual sangat relevan dengan perkembangan dan 
kemajuan sistem manajemen dewasa ini, belum dapat berjalan secara maksimal sehingga diperlukan pengkajian secara ilmiah dengan pendekatan empirik dan manusiawi. Karena keberhasilan manusia dalam berbagai aktivitasnya - khususnya dalam manajemen suatu organisasi-dominan ditentukan oleh faktor human relation.

\section{DAFTAR PUSTAKA}

Boisard, Marcel A. 1980. Humanisme dalam Islam. Terjemahan oleh H. M. Rasyidi. Cet. ke-1. Jakarta: Bulan Bintang.

Echols, John M. \& Hassan Shadily. 1990. Kamus Inggeris-Indonesia. Cet. ke-19. Jakarta: Gramedia.

Effendy, Onong Uchjana. 1993. Human Relation dan Public Relation. Cet. ke-8. Bandung: Mandar Maju.

Fattah, Nanang. 2000. Landasan Manajemen Pendidikan. Cet. ke-3. Bandung: Remaja Rosdakarya.

Jiwanto, Gunawan. 1985. Komunikasi dalam Organisasi. Cet. ke-1. Yogyakarta: Pusat Pengembangan Manajemen Fakultas Ekonomi Universitas Atmajaya.

Muhammad, Arni. 2000. Komunikasi Organisasi. Cet. ke-3. Jakarta: Bumi Aksara.

Muslim, Imam. t.th. Shahih Muslim. Bandung: Syirkatul Ma'arif.

Redaksi Karya Anda. t.th. Kamus Internasional Populer. Surabaya: Karya Anda.

Siagian, Sondang P. 2001. Manajemen Sumber Daya Manusia. Cet. ke-9. Jakarta: Bumi Aksara.

Sya'ban, Fuadi. 1982. Al-Qur'an Membina Jiwa dan Moral Manusia Seutuhnya. Cet. ke-1. Jakarta: Menara Kudus.

'Umar, Mus $\square \mathrm{t} \square$ afâ Muh $\square$ ammad. t.th. Jawâhir al-Bukhârî. Cet. ke-7.. Kairo: Dâr al-'Alâm. 